\title{
The Role of Peter in Early Christian Art: Images from the 4th to the 6th Century
}

\author{
Jutta Dresken-Weiland
}

Images of St. Peter belong to the most frequent themes of early Christian art. I do not intend to give a survey of the different scenes in which Peter appears - I only refer to the study of Roald Dijkstra, ${ }^{1}$ who has most recently made an exhaustive list of all of them. In the entry "Petrus" of the Reallexikon für Antike und Christentum, published in 2015, various aspects of the research on Peter, such as Peter as a historical figure, the interpretation of Peter in early Christian literature and Peter in archaeology, were summarized in compact and reliable form. ${ }^{2}$ This enables to focus on the following questions: Which are the sources of the images of Peter? What did inspire them? How do they relate to the various texts under the name of Peter and to the theological discussions connected with his role? Do the images of Peter tell us anything about his role, and why were they created? What is their function?

In answering this kind of questions, the concept of Anchoring Innovation can help. Images are an important aspect of the process of anchoring Christianity: they make Christianity materially present in the world of antiquity. Their innovative character is expressed by the fact that most of the images are created ex novo, without re-using pagan prototypes.

Peter appears in early Christian art since the third century, together with a series of other images taken from the Old or the New Testament. ${ }^{3}$ Whereas the number of Christian images in the third century is limited, the fourth century

1 Dijkstra (2016) Appendix.

2 See Dassmann, Nicklas, and Wolter (2015).

3 Dresken-Weiland (2011) 126; Dresken-Weiland (2011a) 66 with a survey of Christian images of the third century. 
offers a fairly rich choice of images, and three scenes with Peter are among the most frequent images. ${ }^{4}$

Two of them refer to Peter's activities at Rome. One of them is the water miracle, where Peter, detained in the Mamertine prison, the Tullianum, strikes the rocks with his rod, receives water and baptizes his two guardsmen (fig. 7.1). ${ }^{5}$ Second in occurrence is the arrest of Peter (preceding the water miracle in the chronological sequence of the events), where Peter is depicted between the two guards and in discussion with them (fig. 7.1). ${ }^{6}$ It is well known that this story is mentioned only in outline and only in non-canonical texts, in the Passio Petri, the so-called Pseudo-Linus, ${ }^{7}$ written in Rome between the fourth and the sixth century, ${ }^{8}$ and the Passio of the saints Processus und Martinianus, probably composed in the course of the sixth century. ${ }^{9}$ The baptism of the two jailers is alluded to only shortly in Pseudo-Linus, when Processus and Martinianus ask Peter to escape from imminent martyrdom, whereas the Passio gives a more detailed description. ${ }^{10}$ For the scene of the arrest of Peter, there is no written record. ${ }^{11}$

4 Dresken-Weiland (2010) 19, 21.

5 See also Dijkstra's and Thacker's contribution to this volume.

6 See also Löx's contribution to this volume.

7 Passio Petri 5: 'Even the guards of the prison, Processus and Martinianus, along with the other functionaries and those attached to them by virtue of their office, were making their request, saying: "Master, depart and go where you wish, because we believe that the emperor has already forgotten you. But that most wicked Agrippa, inflamed by love of his concubines and by the extravagance of his own lust, is making haste to destroy you. For if he were attacking you by order of the emperor, we would [already] have the sentence regarding your death from Paulinus, a most illustrious man, from whose keeping you were put into our custody. For after you baptized us believers in the name of the holy Trinity in the nearby Mamertine prison, when a spring and the marvellous sign of the cross had been produced from the rock through prayer, you proceeded freely wherever you wished, and no one caused you any trouble - nor would they now, if the demonic conflagration which is rousing the city had not invaded Agrippa so keenly. For this reason, we beg you, the intermediary of our salvation, to be willing to make us this return: that since you have freed us from the chains of sins and demons, you should go free from the bonds of prison and shackles, whose savagery has been entrusted to us - not so much with our permission as because of our entreaty - for the sake of so many people's salvation.' English translation by Andrew Eastbourne at https://archive.org/stream/ActsOfPseudo-linus/Ps-Linus_ djvu.txt (retrieved at 18.01.2018), p. 5 .

8 Eastman (2015) 29 thinks that a date after the middle of the sixth century is unlikely and opts for a date in the late fourth or the fifth century.

9 Dresken-Weiland (2010) 119f.; edition: Franchi De' Cavalieri (1953).

10 In both texts, it is the sign of the cross that calls forth the water spring, see Lipsius (1890) 110f., 415 .

11 An arrest of Peter is mentioned in Acta Petri 38 , but there are four soldiers to arrest him and to bring him to Agrippa - the situation is a different one. 


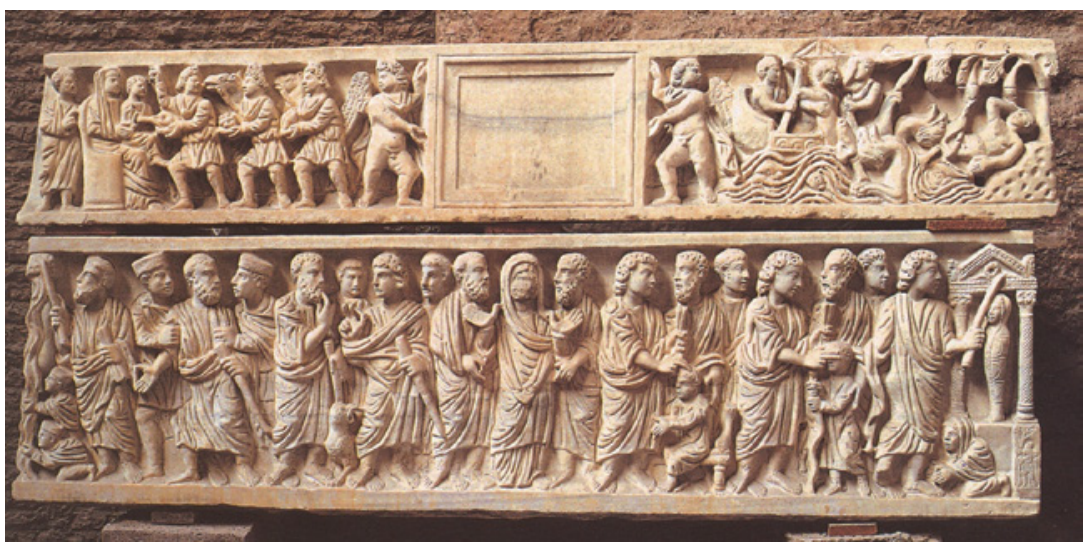

FIGURE 7.1 Rome, Museo Nazionale Romano, frieze sarcophagus, Rep. I nr. 770

This story is attached to a familiar place: the Mamertine prison and the Fons. $S$. Petri in the centre of Rome, ${ }^{12}$ visible and existing for centuries, are the starting points and the pre-existing elements to which Peter's story was attached. Probably, the story was not written down because it was well-known to everyone. The story must have existed no later than the beginning of the fourth century, because it appears on sarcophagi; ${ }^{13}$ probably, it is older, because the water miracle, frequently depicted with the arrest, is already represented on a late-third-century sarcophagus. ${ }^{14}$ It is an interesting example of how religious dynamic places and stories could develop independently from ecclesiastic hierarchy.

The iconography of the water miracle comprises a man with a rod striking water from a rock, and two soldiers who render the scene easily recognizable. The motif of the man with a rod in front of a rock is already used a few times for Moses who strikes water from the rocks in the desert (Ex 17.1-6) in third century catacomb paintings. ${ }^{15}$ It is not necessary to assume that these three paintings in the Catacomb of Calixtus, dated to the second third of the third century, hidden behind doors in private grave rooms, ${ }^{16}$ served as an inspiration for Peter's iconography: the rod and the rock concern the nucleus of both stories and have to be represented imperatively. Although theoretically the creation of this Petrine iconography is possible only on basis of the story, we do

\footnotetext{
12 Coarelli (1993) 236f.; de Spirito (1995) 261.

13 Rep. II, nr. 11 (Capua).

14 Rep. I nr. 35. For a different interpretation see e.g. Cascianelli (2017).

15 Dresken-Weiland (2010) 124-31, 146, 332-4.

16 Cubiculum A 2 (Wilpert [1903] pl. 27,2), A 3 and A 6 (Wilpert [1903] pl. 46,1).
} 
not know how many images of Moses' miracle existed which may have been used as a prototype. ${ }^{17}$ The relation between Peter and Moses is mentioned in theological texts since the later fourth century, ${ }^{18}$ but it may have been much older. The scene of the arrest does not go back to any specific iconographic pattern. ${ }^{19}$

The creation and the frequency of these two scenes are clearly inspired by the veneration of Peter in Rome, documented by the veneration of his burial place since the later second century, and expressed in the construction of his basilica by Constantine. Nonetheless it is interesting that these images are particularly popular on marble sarcophagi. The use of these (and other) Peter images on sarcophagi may be interpreted in different ways:

1. The commissioners and the dead buried in such a sarcophagus expected help from the prince of the apostles in the period between death and doomsday and on the day of the final judgement. ${ }^{20}$

2. It is possible that the water miracle alludes to the baptism of the "owners" of the sarcophagus, because it was practised on deathbed very frequently.

3. A further aspect of the content and signification of these images appears looking at the commissioners and the place of inhumation: The inscriptions of the sarcophagi teach us that members of the upper class more frequently appear among the commissioners of Christian than earlier pagan sarcophagi. ${ }^{21}$ This means that the prince of the apostles probably played an important role for the Roman upper class: the church of St. Peter, the most noble and top-ranking Christian sanctuary of Rome, was also the most prestigious cemetery. A considerable number of sarcophagi was found there, and Peter appears in their iconography very frequently. ${ }^{22}$ It is striking that Paul, on the contrary, appears on sarcophagi only rarely, although his veneration is documented for example in the graffiti in S. Sebastiano and in the imagery of the Roman gold glasses. ${ }^{23}$ I have

17 See for instance an engraved bronze ring in a private collection, which shows 'Moses striking the rock', Spier (2007) $186 \mathrm{nr}$. R 65, attributed to the later fourth and fifth century, referring to Chadour (1994) 134 nr. 461.

18 Dresken-Weiland (2010) 123 f.

19 Dresken-Weiland (2016) $146 f$.

20 Cf. the graffiti from the Triclia of S. Sebastiano, Binsfeld (2006) 54-67.

21 Dresken-Weiland (2003) 45-7.

22 Sarcophagi with unspecified apostles are not mentioned. One or more scenes with Peter: Rep. I: 28, 35?, 41, 52, 53, 57, 85, 674, 675, 676, 677, 679, 689, 919, 987, 1008. See also the catalogue in Dresken-Weiland (2003) 371-81.

23 See Binsfeld (2006) and Morey (1959) 78 with a list of inscriptions which mention Peter and/or Paul. For the graffiti cf. also the contribution by Van den Hoek in this volume. 
argued elsewhere that the outstanding veneration of Peter by members of the Roman upper class may be explained by their self-concept. They chose images of the man who was venerated as the founder of the Roman community and successor of Christ, because they saw themselves as the elite of the city of Rome and associated themselves with images of the prince of the apostles who founded the Roman church. ${ }^{24}$ This is further corroborated by the fact that these images are rare in catacomb paintings, attributed to middle class Christians: the arrest of Peter is not represented at all and his water miracle only rarely. ${ }^{25}$

Of course, the veneration of Peter and the story of Peter in Rome were appealing to all Christians. This shows the representation of the water miracle outside the funeral realm on objects of daily life: A bronze lamp preserved in the Archaeological Museum of Florence and dated to the fourth century ${ }^{26}$ may have been used in a middle-class household, also a glass casket from Neuss/ Novaesium ${ }^{27}$ and an incised glass from Obernburg now in Munich. ${ }^{28}$ The water miracle appears also on gold glasses, which served in different contexts. ${ }^{29}$

These two Peter scenes are an excellent example of the anchoring innovation process: The Peter stories are attached to a particular place in the centre of Rome, and they were so well-known that they were not written down and left only faint traces in later texts. With this story the images giving Peter, who had certainly been venerated before, the role of a local Roman hero, anchored Christianity deeply in the minds and memory of fourth-century Christians.

The venerated place, the water spring and the prison of Peter had a much longer life than the images: they were still visited by medieval pilgrims, ${ }^{30}$ whereas images of these two Petrine scenes are mostly limited to the fourth century.

24 Dresken-Weiland (2010) 144-46.

25 In the catacomb of Callixtus, nr. 45, Wilpert 1903, pl. 237 (one soldier): anonymous catacomb of Via Anapo: Deckers, Mietke, Weiland (1994), colour pl. 26 (two soldiers); catacomb of Marcus and Marcellianus: Saint-Roch (1999) 102 fig. 41 (one soldier); Catacomb of Tecla: Wilpert (1903) pl. 234,3 (one soldier); anonymous catacomb of Via Latina: Ferrua (1990) 50 fig. 39 (two soldiers). See the complete list of all representations of the water miracle in Nestori (1993) 214.

26 B. Mazzei, Lampada con il miracolo della fonte. In: Donati (2000) 125, $206 \mathrm{nr} .45$.

27 Dresken-Weiland (2010) 122 n. 150; Päffgen (2005) 122f.

28 Couzin (2015) 117 fig. 51.

29 L. Vattuone, Vetro dorato con Pietro nel miracolo della fonte. In: Donati (2000) 125, 206 nr. 44; Dresken-Weiland (2017a) 51f. Also the water miracle of Moses is represented on gold glasses of the later fourth century: Howells (2015) 106-107 nr. 19.

Fons sci petri ubi est carcer eius in the Anonymous Einsidlensis, Bauer (1997) 197. 


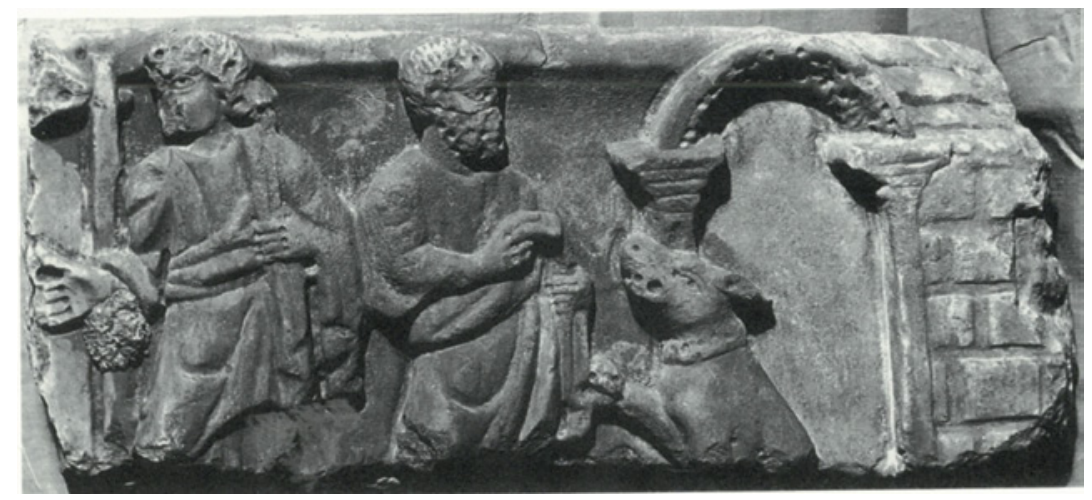

FIGURE 7.2 Kraków, Museum Narodowe, fragment of a sarcophagus lid with Peter and the dog of Simon magus, Rep. II nr. 225

Another famous story is Peter's dispute with Simon Magus (Acta Petri 9$)^{31}$ also localised in Rome. It is told in the Actus Vercellenses, a Latin translation from a Greek manuscript written in the late fourth century in a western scriptorium in Spain or North Africa. ${ }^{32}$ The story must have been widely known, but only one scene is depicted: Peter with the (speaking) dog of his adversary is represented on a few sarcophagi of the late fourth century (fig. 7.2), and appears only on their lids, what shows that it was considered of minor importance. ${ }^{33}$ When the lid is completely preserved, it is combined with the scene of Daniel poisoning the Babylonian serpent. ${ }^{34}$ Both scenes offer a parallel constructed iconography and it is possible that they were chosen for this reason: both present a miracle story.

It is difficult to explain why this famous dispute, which is later represented in Peter cycles starting from ca. $700 \mathrm{CE},{ }^{35}$ is not more popular in early Christian art. Maybe the water miracle was localized better in its well-known "historical" place in the centre of Rome, or the possible reference to baptism included in this scene was more interesting for contemporaries: conversion to Christianity certainly was an important theme in late-fourth-century Rome. Possibly the

\footnotetext{
$31 \quad$ Nicklas (2015) 417f.

32 Baldwin (2005) 193, 302-14.

33 Rep. II nr. 151, 152, 225, III nr. 304, 418.

34 Rep. II nr. 151. $15^{2}$.

35 Weis (1963) 241, 245 .
} 
water miracle was in this sense more helpful to "anchor christianity" than a more or less spectacular story that had neither a reference to personal decisions and creed nor an established location.

\section{3}

\section{Peter, Christ and the Cock}

The third popular and frequently represented Peter scene shows Peter, Christ and the cock (fig. 7.3). The presence of the cock indicates that the image is connected with Peter's denial, but it cannot be attributed to a definite situation. ${ }^{36}$ In the announcement of Peter's denial, ${ }^{37}$ the cock may illustrate the content of the dialogue between Christ and Peter, but there is no need of an actual cock's presence. After Peter's denial, ${ }^{38}$ Christ is absent. In the assignment of Peter with the pastorate, ${ }^{39}$ the cock is absent of course, but it refers to the denial of Peter indirectly, when he is asked thrice by Christ. The scene with the cock in early Christian art should therefore be referred to as a multi-layered image.

Iconographically the figures of Christ and Peter refer to the elements of philosophical teaching. With the movement of his right hand, Christ is shown as speaking, whereas Peter grabs his chin or his beard, and thus appears as listening with attention, commitment and consternation. This iconography can be found on pagan sarcophagi of the third and the early fourth century ${ }^{40}$ and was familiar to the contemporary spectator. When the first representations of this scene appeared at the beginning of the fourth century, he must have recognized the reference to philosophical imagery. ${ }^{41}$

The use of this iconography is important for the understanding of this scene. In early Christian literature, the denial of Peter was intensely discussed, ${ }^{42}$ even the severity of his mistake. The choice of the philosophic iconography puts Peter's denial in a widespread and positively connoted context, which is

$3^{6}$ Of course, this scene is located in Palestine, but geography rarely matters in early Christian art.

37 Mentioned by all four evangelists: Mt 26.33-35; Mk 14. 26-31; Lk 22.31-34; Joh 13.36-38.

38 Also mentioned by all four evangelists: Mt 26.69-75; Mk 14. 66-72; Lk 22.53-62; Joh $18.15^{-25}$.

39 Only reported in Joh $21.15^{-18}$.

40 Ewald (1999) nr. A 28 pl. 16,2 in S. Lorenzo (third century); nr. D 4 pl. 41 in the Palazzo Balestra (end of the third century); nr. D 9 pl. 46,5 in the Museo Nazionale Romano (beginning of the fourth century.); nr. G 17 pl. 90 in the Musei Vaticani (275-280), nr. I 16 pl. 104,5 in the Palazzo Merolli (second half of the third century), nr. I 18 pl.104,5 in San Severino Marche (second half of the third century).

41 One of the first examples is represented on a sarcophagus in Pisa, Rep. II, nr. 12.

42 Dresken-Weiland (2010) 148f.; Nicklas (2015) 424f. 


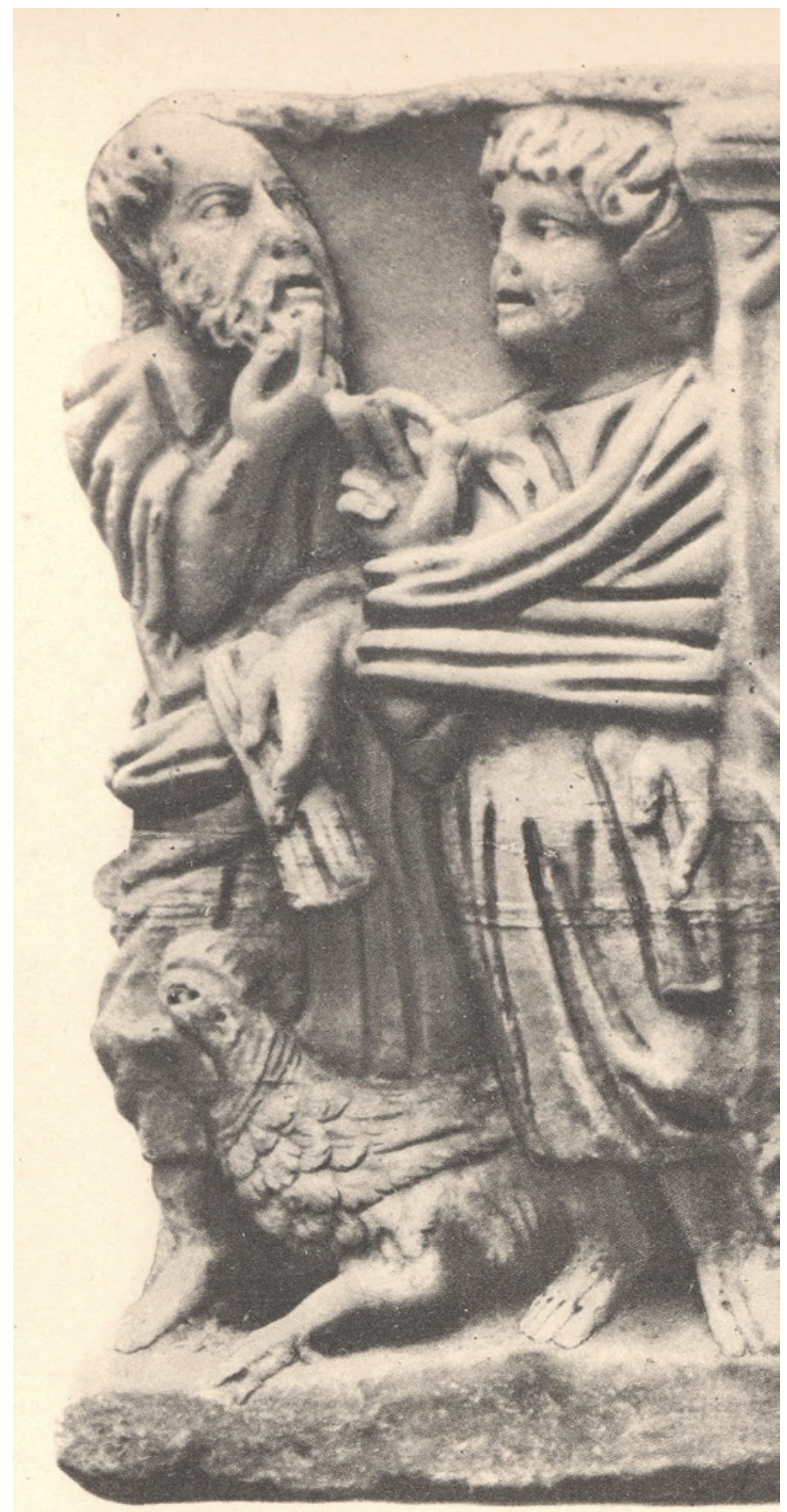

FIGURE 7.3 Rome, Ospedale S. Spirito, sarcophagus with Peter, Christ and the cock, J. Wilpert, I sarcophagi cristiani antichi I, Roma 1929, pl. 92,1 
presentable in a society deeply interested in education, literature and philosophy. I think that this iconography was created to take up the discussions (by theologians and laymen) about Peter's frailty and to create an image which offers a familiar point of contact for Christians and non-Christians. Possibly the beholder could also reflect about personal shortcomings and mistakes.

Looking at theological texts, the scene of Peter, Christ and the cock has been interpreted as an image which stands for the forgiveness of sins, grace and mercy, the hope for afterlife and resurrection. ${ }^{43}$ The importance of this theme is underlined by its position on sarcophagi: in contrast to the arrest of Peter and the water miracle, which is often placed at the corner, this scene frequently occupies the centre of sarcophagus fronts. ${ }^{44}$ It is one of the few longliving themes which can be found throughout the fourth century and even thereafter. ${ }^{45}$ The arrest and the water miracle appear only rarely after the end of the fourth century. ${ }^{46}$ When the arrest and the water miracle are more or less mere "stories" about Peter in Rome, the scene with the cock transports "content". It presents aspects of Peter's denial in an elegant and familiar form which makes it possible to discuss a negative behaviour of the prince of the apostles and even of the personal life of the beholder.

It is this "content" which is the motivation for creating and depicting this scene: while Christianity was anchored via the images of one of the most important apostles, the less heroic and less exemplary moments should also be illustrated - in a familiar iconography which offered even clues for identification.

Outside of funerary art this scene appears only on ivories and on mosaics ${ }^{47}$ and in cycles of the passion of Christ. In the mosaics of San Apollinare Nuovo in Ravenna, made in the first quarter of the sixth century, there are two scenes dealing with the topic: the annunciation of the denial with Christ and the cock, and Peter with the maid contesting that he belongs to Jesus' group. ${ }^{48}$ On the ciborium column D in San Marco in Venice, dated to the first half of the sixth century, there are even three scenes: the maid speaking to Peter, who raises his hands in a gesture of defence, Peter grasping his beard while sitting before a column with the cock on top of it, and Peter standing and weeping with a cloth

\footnotetext{
43 Dresken-Weiland (2010) 146-62.

44 Dresken-Weiland (2010) 155.

45 For byzantine and Carolingian representations see Hahn (1977) 47-61.

46 A late example: ivory plaques in the British Museum with scenes from the Acts of the Apostles and the apocryphal water miracle, see Van den Hoek (2013) 304 fig. 2, Koenen (2013).

47 See Post (1984) 168-73.

48 Dresken-Weiland (2016) 148-51.
} 
to dry his tears. ${ }^{49}$ This shows that Peter's "betrayal" was an important theme for Christians from the fourth to the sixth century and also later and that it was worth dealing with it.

\section{4}

\section{Dominus legem dat}

When Christian culture appeared, new images had to be created for new places and contexts. So it is obvious that for the apse of the basilica erected in honour of the tomb of Peter, none of the images that already existed, were adequate; scenes from Peter's life in Rome would not fit the form of an apse, and his death at the cross would not be acceptable in public (neither was the death of Christ)..$^{50}$ According to a quasi-generally accepted hypothesis, the "Dominus legem dat", the most discussed scene in early Christian art, was created for the apse of St Peter's basilica. ${ }^{51}$ The apse mosaic is dated to the reign of Constantine I, according to the various inscriptions in the apse, in the arch of the apse and on the triumphal arch (fig. 7.4). ${ }^{52}$

The problem of the iconography is that it cannot be linked to written sources. It shows Christ on the paradise mountain between Peter and Paul. Christ has raised his right arm and holds in his left hand an opened scroll, which Peter, who is bent forward while approaching, collects with his cloak. Let us take a closer look at its iconography in order to understand the reasons for the invention of this image for this public place.

This scene is labelled Dominus legem $d a t^{53}$ by a series of original inscriptions connected with it. ${ }^{54}$ Christ does not consign anything, because in that case he would be seated, as is known from similar images in imperial iconography. When he hands over something, he does this with his right hand - for example when he gives the keys to Peter. ${ }^{55}$ However, here Christ is standing and has raised his hand, which characterizes him as speaking and proclaiming. This gesture of speech and promulgation is well known from imperial iconography, ${ }^{56}$ but there the emperor never holds a scroll. The scroll and a

\footnotetext{
49 Lucchesi Palli (1942) 64 Taf. III; Weigel (1997) 280; Dresken-Weiland (2016), 15 of.

50 For images of the crucifixion see Dresken-Weiland (2013). On violence in early Christian art see recently Amodio (2016) and also the contribution by Löx in this volume.

$5^{1} \quad$ Arbeiter (2007) 145; Brenk (2010) 55; most recently Brandenburg (2017) 53-61.

52 Liverani (2015) 492-6; Liverani (2016) 1394-96; Brandenburg (2017) 58-61.

53 Essential for the understanding of this scene is Arbeiter (2007) 124-147; Couzin (2015).

54 Arbeiter (2007) 118, 128-132 with n. 278, 133, 145, see also Couzin (2015) 40-43.

55 Arbeiter (2007) 146.

56 Couzin (2015) $26 f$.
} 


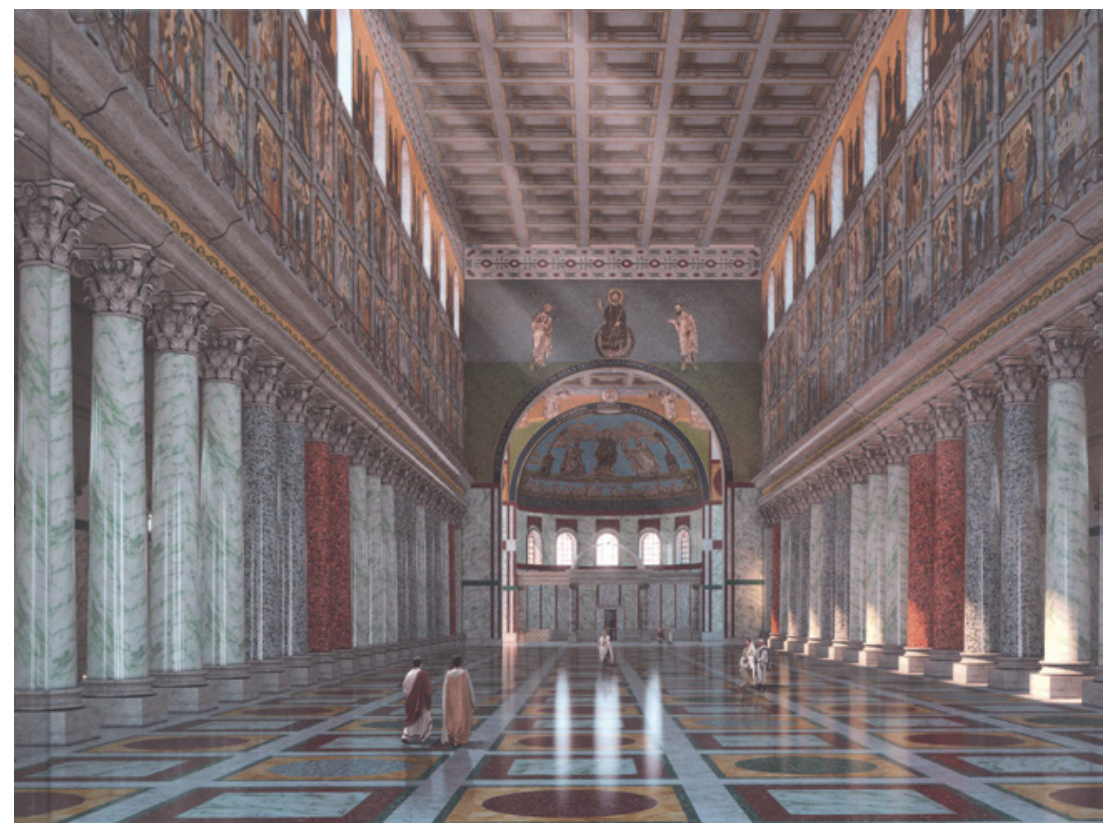

FIGURE 7.4 St. Peter's, Reconstruction of the interior

person taking it over refer to the scene of Moses receiving the law, but the iconography of these two images offers a series of differences. Therefore, one cannot be certain whether this visual quotation is really meant. ${ }^{57}$

For Christ, it is very unusual to be represented as the promulgator; generally, when Christ is represented in Constantinian images, he is either shown as a miracle worker, or as teacher, with his right hand before his chest or next to it, with a raised forefinger and/or middle finger - we have seen this iconography in the scene of Peter's denial. The raised hand with outstretched fingers seems to be limited to this scene.

The roll whose content he is proclaiming probably signifies the gospel, which Christ has nearly finished. As Robert Couzin has pointed out, Jesus' last words in the Gospel, as recorded especially in Matthew 28:19-20 and Mark 16:14-15, present a parting evangelical instruction to his disciples: to go out into the world and "teach all the nations ... to observe that what I have commanded or taught you" (Matthew), or "preach the Gospel to every creature" (Mark). In this image, the instruction has become an announcement and the teaching or

57 Couzin (2015) 49-51. 
commandments pithily compressed into the "law",58 with Peter who is here presented with special emphasis as the favoured commissioner.

In the context of this promulgation, Peter receiving the opened scroll has a special role; authority and particular importance are adjudged to him, which is also underlined by the cross rod he is bearing. Paul is added as the second apostle of Rome, as he is addressed in theological texts since the second half of the second century; ${ }^{59}$ besides, his figure helps to create a balanced and symmetrical image. For the content of the image, the apocalyptic elements such as the hill of paradise with the four Paradise Rivers and the apocalyptic clouds are important. They show that the promulgation of the law is not only a historical event, but is also time-transcending and simultaneous with the future apparition of Christ at doomsday. ${ }^{60}$

Why has this image been chosen for the apse of St Peter's? It was seen first of all by the church visitors in a time in which Christianity started its triumphant success. The use of imperial iconography, an imperial gesture of power and majesty in the figure of Christ should be emphasized. Christ proclaims his "law" of faith and salvation and charges Peter, around the tomb of whom this lavishly decorated basilica was constructed, as a privileged missionary. The emperor, whose iconography is used, wants this faith to be taught to all nations. The Dominus legem dat thus seems to me an iconography with a strong political overtone.

Images of Peter and Paul appear also on less eye-catching objects. ${ }^{61}$ They are depicted frequently on gold glasses, generally attributed to the fourth century and were mostly produced in Rome. ${ }^{62}$ It has been suggested that these were used in ceremonies in honour of the dead, as the inscriptions insinuate; the

\footnotetext{
$5^{8} \quad$ Couzin (2015) 45 .

59 Van den Hoek (2013) 308 with reference to Irenaeus of Lyon; see also her contribution to this volume.

6o Kaiser-Minn (1983) 331 emphasizes the christological aspect of the scene: 'die Selbstoffenbarung des kosmischen und endzeitlichen Siegers Christus, des Allherrschers und Gesetzgebers (und -vollstreckers) vor den Aposteln, die zu seinem Dienst bereitstehen'.

61 See a list of the iconographies in the index in Morey (1959) 82. Frequently cited are Huskinson (1982) 51-59 and Kessler (1987) 265-275. For the apostle's portraits see recently Croci (2013) 48-51; Paneli (2014) 85f.; Felsner (2014) 75-90. Incomplete in respect to nonEnglish literature is Meredith (2015).

62 See recently Howells (2015) $57 \mathrm{f}$.
} 
saints represented were expected to help the deceased in the time between death and resurrection. ${ }^{63}$ This means that their function is the same as that of the images of Peter on sarcophagi.

The apostolic iconography on gold glasses mostly shows both apostles facing each other. This motif, which is generally labelled as Concordia apostolorum, is known since the second century from Roman imperial coinage: two rulers turn towards each other and shake hands, with the addendum concordia. ${ }^{64}$ The addendum concordia, does not, however, appear on any of these glass roundels. Furthermore, on coins there are never two heads facing each other, but always two persons, the figure of Concordia alone or a single head. One could doubt whether the traditional name is accurate. Looking at the details of the iconography, Peter and Paul are very frequently represented with a crown above them ${ }^{65}$ or with Christ holding a crown above their heads. ${ }^{66}$ "The coronation of the apostles" seems to be a more appropriate modern name. Similar iconography is used also in other contexts: Christ with a wreath or a crown in his hand holds it above other saints' or a couple's heads. ${ }^{67}$ For the other images of Peter and Paul, no specification seems to be necessary other than the descriptive designation "heads or figures of the apostles Peter and Paul".68

Obviously this image is a further reminder of the princes of the apostles' presence in Rome, mentioned already in early texts ${ }^{69}$ - in a group of objects that was certainly much more affordable than a marble sarcophagus. ${ }^{70}$ It also shows that the need and the hope for the apostle's intercession was widespread and was anchored among a larger group of people. The final destination of the glass roundels as decoration of catacomb loculi emphasizes the function of the images in the context of private devotion and confidence in the apostle's assistance.

The representation of the apostles face to face has nothing to do with the dispute between the apostles in Galatians 2:11-14. There is no image which

\footnotetext{
63 Dresken-Weiland (2017b), 51f.

64 For the iconography of Concordia see Hölscher (1990).

65 Morey (1959) 53, 60, 61, 62, 63, 65, 67, 242, 267, 277, 396 (?). See now also the tetrarchic relief of embracing emperors, recently found in Nicomedia: Şare Ağtürk (2018).

66 Morey (1959) 50, 58, 66, 241, 286; see recently Howells (2015) 79f. nr. 10.

67 Saints: Morey (1959) nr. 74, 102. Couple: Morey. nr. 29, 109; Howells (2015) 124 pl. 103, 129 fig. 24.

68 For the image of Peter and Paul embracing each other, a theme from the second half of the fourth century, the name concordia apostolorum seems to fit better. See Guj (2002) 1873-91.

69 Grünstäudl (2015) 413-414; for the discussion about the Roman Peter-tradition see most recently Gnilka (2018).

$70 \quad$ Howels (2013) 119 .
} 
can be interpreted in this sense. In this context, a relief with Peter and Paul in Aquileia should be presented briefly. ${ }^{71}$ It is not worked out completely and shows the apostles facing each other, Peter on the left and Paul at the right. Paul holds his mantle from inside with his right hand. A similar motif is found in the famous statue of the Greek poet Sophocles and interpreted as a sign of elegance and erudition..$^{72}$ Whether Peter was to perform a similar movement cannot be decided because the relief was never finished. Paul's reference to erudition shows how important classical culture was for those who created images for the new religion. Unfortunately, we do not know the context for which this relief was commissioned.

The primacy ${ }^{73}$ of the Roman church seems to have been no theme for images, apart from the emphasis on Peter and Paul as the (alleged) founders of the Roman church and their shared martyrdom at Rome. A group of statuettes of Peter, for which a chronology in the $5^{\text {th }}-6$ th century has been proposed earlier on the basis of an archaeometric analysis ${ }^{74}$ are now dated to the 19th century. ${ }^{75}$ The traditio clavium, which appears since ca. 370 in early Christian art (see fig. 7.5, a sarcophagus fragment from the Campo Santo Teutonico in Rome), is neither depicted frequently nor commented by theologians in the context of primacy ${ }^{76}$ Therefore, we do not know any images which refer to the primacy of the bishop of Rome; consequently, this subject appears to have been of little interest to Christians in the fourth century. This is the reason why no images referring to it were created.

The concept of "Anchoring innovation" reveals itself a useful tool when reflecting on the invention and the insertion of Peter images in early Christian art. Not all Peter images were successful, only a few were represented frequently. Two successful images, the arrest and the water miracle, refer to local "storytelling"

\footnotetext{
$71 \quad$ Dassmann (2015) 438: "Apostelkuss"; Dresken-Weiland (2017b) 125.

72 Statue of Sophocles, see Vorster (1993) 154-159, nr. 67 fig. 297-30o.

73 Wirbelauer (2016) 156-83.

74 Fourlas (2006) 79-85; (2008) 141-68.

75 Cassitti, Berger, Fourlas (2013) 323-58.

76 Dresken-Weiland (2011) 147-9; Dijkstra (2018).
} 


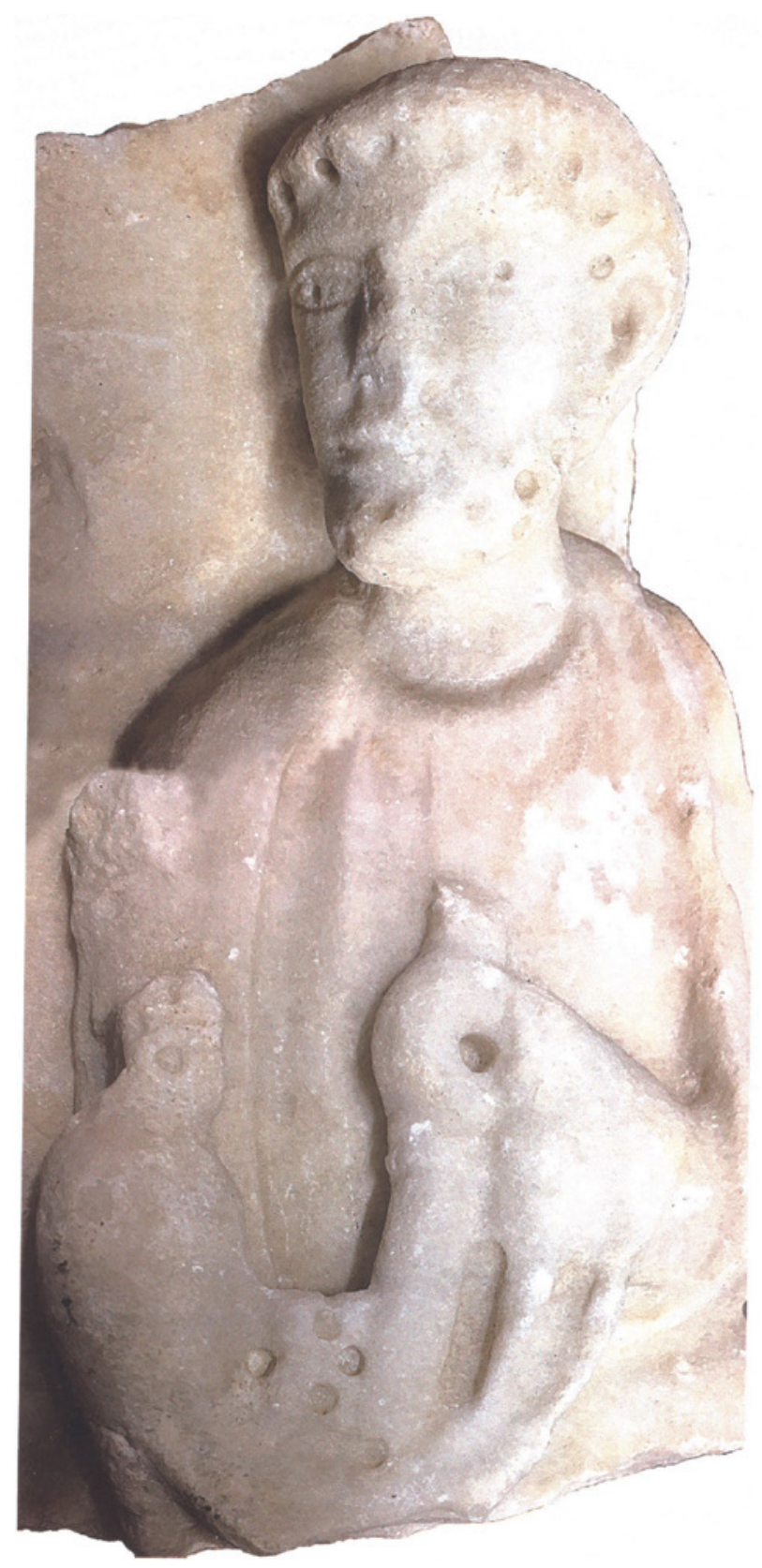

FIGURE 7.5 Rome, Campo Santo Teutonico, sarcophagus

fragment with the traditio clavium 
about Peter in Rome and make his veneration visible in material culture. In the sepulchral sphere, images of Peter express the hope of the commissioners that the prince of the apostles would help in the hereafter. The invention of the dominus legem dat for the apse of St Peter's is an example of the necessity to invent new images for new places and new contexts.

Generally speaking, Peter scenes obviously serve also as a horizontal anchor for Christianity, because they are present in different contexts and in various types of monuments, from small gold glasses to church mosaics. The diversity of Peter images at different times also shows that innovation has to be made constantly, because the durability of images is limited. That is why only few Peter images survive into the Middle Ages.

\section{Bibliography}

Amodio, M. 2016. Violenza celata, evocata, sublimata: "martiri sventati" nell'arte cristiana delle origini. Analysis archaeologica 2: 5-14.

Arbeiter, A. 2007. Die Mosaiken. In: J. J. Rasch \& A. Arbeiter, Das Mausoleum der Constantina in Rom, 103-313. Mainz: Zabern.

Baldwin, M. C. 2005. Whose act of Peter? Text and Historical Context of the Actus Vercellenses. Tübingen: Mohr Siebeck.

Bauer, F. A. 1997. Das Bild der Stadt Rom in karolingischer Zeit. Der Anonymus Einsidlensis. $R Q A$ 92: 190-228.

Binsfeld, A. 2006. Vivas in deo. Die Graffiti der frühchristlichen Kirchenanlage in Trier. Trier: Selbstverlag des Bischöflichen Dom- und Diözesanmuseums.

Brandenburg, H. 2017. Die konstantinische Petersbasilika am Vatikan in Rom. Anmerkungen zu ihrer Chronologie, Architektur und Ausstattung. Regensburg: Schnell und Steiner.

Brenk, B. 2010. The Apse, the Image and the Icon. An Historical Perspective of the Apse as a Space for Images. Wiesbaden: Reichert.

Cascianelli, D. 2017. Il ritorno di Mosè. Per una rilettura delle presunte scene petrine del sarcofago di Giona. RAC 93: 137-166.

Cassitti, P. Berger \& D. Fourlas, 2013. 'St Peter in Volders' and related base metal figurines resembling the famous statue in the Vatican Basilica. Post-Medieval Archaeology $47(2): 323-58$.

Chadour, A. B. 1994. Ringe, Rings. Die Alice und Louis Koch Sammlung. Vierzig Jahrhunderte durch vier Generationen gesehen. The Alice and Louis Koch Collection. Forty Centuries seen by Four Generations. Leeds: W. S. Maney.

Coarelli, F. 1993. Carcer. In Lexicon topographicum urbis Romae I, 236f. Roma: Edizioni Quasar. 
Couzin, R. 2015. The traditio legis. Anatomy of an image. Oxford: Archaeopress.

Croci, Ch. 2013. Portraiture on Early Christian Gold-Glasses: Some Observations. In The Face of the Dead and the Early Christian World, ed. I. Foletti, 43-59. Roma: Viella.

Dassmann, E. 2015. Petrus III. Ikonographie und Kult. In RAC 27: 427-55. Stuttgart: Hiersemann.

Dassmann, E. 2015a. Paulus IV. Ikonographie und Kult. In $R A C$ 26: 1229-50. Stuttgart: Hiersemann.

Deckers, J. G., G. Mietke \& A. Weiland. 1995. Die Katakombe „Commodilla“. Repertorium der Malereien. Città del Vaticano: Pontificio Istituto di Archeologia Cristiana.

Dijkstra, R. 2016. The Apostles in Early Christian Art and Poetry. Leiden: Brill.

Dijkstra, R., 2018. Imagining the Entrance to the Afterlife. Peter as the Gatekeeper of Heaven in Early Christianity. In Sacred Thresholds. The Door to the Sanctuary in Late Antiquity, ed. E. B. van Opstall, 187-218. Leiden/Boston: Brill.

Donati, A. (ed.) 200o. Pietro e Paolo. La storia, il culto, la memoria nei primi secoli. Milano: Electa.

Dresken-Weiland, J. 2003. Sarkophagbestattungen des 4.-6.Jhs. im Westen des Römischen Reiches. Freiburg: Herder.

Dresken-Weiland, J. 2010. Bild, Wort und Grab. Untersuchungen zu Jenseitsvorstellungen von Christen des 3.-6. Jahrhunderts. Regensburg: Schnell und Steiner.

Dresken-Weiland, J. 2011. Petrusdarstellungen und ihre Bedeutung in der frühchristlichen Kunst. In Petrus in Rom. Akten der IV. Tagung zur frühen Kirchengeschichte im Campo Santo Teutonico 2010, ed. S. Heid, 126-52. Freiburg: Herder.

Dresken-Weiland, J. 2011a. Bilder im Grab und ihre Bedeutung im Kontext der Christianisierung der frühchristlichen Welt. Antiquité tardive 19, 63-78.

Dresken-Weiland, J. 2013. A new iconography in the face of death? A sarcophagus fragment with a possible Crucifixion scene in the Museo Pio Cristiano. In The face of the dead and the early Christian world, ed. I. Foletti, 133-48. Roma: Viella.

Dresken-Weiland, J. 2016. Die frühchristlichen Mosaiken von Ravenna. Bild und Bedeutung. Regensburg: Schnell und Steiner.

Dresken-Weiland, J. 2017a. Relief mit Darstellung der Apostel Petrus und Paulus. In: Die Päpste und die Einheit der lateinischen Welt, ed. A. Wieczorek, S. Weinfurter, 125. Regensburg: Schnell und Steiner.

Dresken-Weiland, J., 2017b. Transformation and Transition in the Art of Late Antiquity. In: Late Antiquity in Contemporary Debate, ed. R. Lizzi Testa, 38-55. Cambridge: Cambridge Scholars Publishing.

Eastman, D. L., 2015. The ancient martyrdom accounts of Peter and Paul. Atlanta: SBL.

Ewald, B. 1999. Der Philosoph als Leitbild. Ikonographische Untersuchungen an römischen Sarkophagreliefs. Mainz: Zabern.

Felsner, J. 2014. Römische Zwischengoldgläser mit Bildern von Martyrern und Heiligen Eine Auswahl. Mitteilungen zur Christlichen Archäologie in Österreich 20: 75-90. 
Ferrua, A. 1990. Catacombe sconosciute. Una pinacoteca del IV secolo sotto la Via Latina Florence: Nardini.

Fourlas, B. 2006. Eine Statuette des thronenden Petrus: Nachbildung einer Monumentalstatue des Apostelfürsten im spätantiken Rom? In Tu es Petrus. Bilder aus zwei Jahrtausenden, ed. H. Reidel e.a., 79-85. Regensburg: Schnell und Steiner.

Fourlas, B. 2008. Die Statuette des Petrus im Museum der Westfälischen WilhelmsUniversität Münster und ihre Beziehung zur Bronzestatue Petri im Petersdom in Rom. Boreas 28/29: 141-168.

Franchi De'Cavalieri, P. 1953. Della custodia Mamertini e della Passio Ss. Processi e Martiniani. Note agiografiche 9: 3-52.

Gnilka, Ch. 2018. Simon magus und die römische Petrustradition. RQA 113: 151-165.

Grünstäudl,W. 2015. Petrus II (in der Literatur). RAC 27:409-421. Stuttgart:Hiersemann.

Guj, M. 2002. La concordia apostolorum nell'antica decorazione di San Paolo fuori le mura. In Ecclesiae urbis. Atti del congresso internazionale distudi sulle chiese di Roma (IV-X secolo), ed. F. Guidobaldi \& A. G. Guidobaldi, 1873-1891. Città del Vaticano: Pontificio Istituto di Archeologia Cristiana.

Hahn, S. 1977. Die Darstellung der Verleugnung und Reue Petri. Ikonographische Studie. München: Hochschulschrift.

Hölscher, T. 1990. Homonioa/Concordia. In LIMC V, 478-498. Zürich/München: Artemis.

Howels, D. Th. 2013. Making Late Antique Gold Glass. In New Light on Old Glass: Recent research on Byzantine Mosaics and Glass, ed. Ch. Entwistle \& L. James, 112-120. London: The British Museum.

Howells, D. Th. 2015. A catalogue of the Late Antique Gold Glass in the British Museum. London: The British Museum.

Huskinson, J. 1982. Concordia Apostolorum. Christian Propaganda at Rome in the Fourth and Fifth Centuries. A Study in Early Christian Iconography and Iconology. Oxford: BAR.

Kaiser-Minn, H. 1983. Die Entwicklung der frühchristlichen Sarkophagplastik bis zum Ende des 4. Jhs. In Spätantike und frühes Christentum, ed. D. Stutzinger, 318-338. Frankfurt: Liebieghaus Museum Alter Plastik.

Kessler, H. 1987. The meeting of Peter and Paul in Rome. An emblematic narrative of spiritual brotherhood. In DOP 41: 256-275.

Koenen, U. 2013. Drei Elfenbeintafeln von einem Kästchen mit Szenen aus dem Leben des Petrus und Paulus. In Credo. Christianisierung Europas im Mittelalter, ed. Ch. Stiegemann, 59-61 (nr. 44). Petersberg: Imhof.

Lipsius, R. A. 1890. Die apokryphen Apostel-Geschichten II. Braunschweig: C. A. Schwetschke und Sohn.

Liverani, P. 2015. Old St. Peter's and the emperor Constans? A debate with G. W. Bowersock. JRA 28: 492-496. 
Liverani, P. 2016. Il monumento e la voce. In Acta XVI congressus internationalis archaeologiae christianae, Romae 2013, O. Brandt \& G. Castiglia, 1394-1396. Città del Vaticano: Pontificio Istituto di Archeologia Cristiana.

Lucchesi Palli, E. 1942. Die Passions- und Endszenen Christi auf der Ciboriumsäule von San Marco in Venedig. Praha: Böhmisch-Mährische Druck- und Verlagsaktiengesellschaft.

Meredith, H. G. 2015. Engaging Mourners and Maintaining Unity: Third and Fourth Century Gold-Glass Roundels from Roman Catacombs. RRE 1: 219-41.

Morey, Ch.R. 1959. The gold glass collection of the Vatican Library. Città del Vaticano: Biblioteca Apostolica Vaticana.

Nestori, A. 1993. Repertorio topografico delle pitture delle catacombe romane. Città del Vaticano: Pontificio Istituto di Archeologia Cristana.

Nicklas, T. 2015. Petrus II (in der Literatur). In $R A C$ 212: 399-427. Stuttgart: Hiersemann. Päffgen, B. 2005. Der spätrömische Sarkophagfund des Jahres 1847 vom Neusser Obertor und das darin beigegebene Frühchristliche Goldglaskästchen. In Cum grano salis. Beiträge zur europäischen Vor- und Frühgeschichte. Festschrift für Volker Bierbrauer zum 65. Geburtstag, V. Bierbrauer, B. Päffgen, E. Pohl \& M. Schmauder, 111-127 Friedberg: Likias-Verlag.

Paneli, E. 2014. Entwicklung der Ikonographie der zweifigurigen Bildkompositionen (mit Ehepaaren oder Heiligen) auf römischen Zwischengoldgläsern. In JbAC 55: 79-89.

Post, P. G. 1984. De haanscène in de vroeg-christelijke kunst. Een iconografische en iconologische analyse. Heerlen: s.n.

Şare Ağtürk, T. 2018. A new tetrarchic relief from Nicomedia: Embracing emperors. AJA 122: 411-426.

Saint-Roch, P. 1999. Le cimetière de Basileus ou Coemeterium Sanctorum Marci et Marcelliani Damasique. Città del Vaticano: Pontificio Istituto di Archeologia Cristiana.

Spier, J. 2007. Late Antique and Early Christian Gems. Wiesbaden: Reichert.

De Spirito, G. 1995. Fons S. Petri. In LTUR II: 261. Roma: Edizioni Quasar.

Van den Hoek, A. 2013. The saga of Peter and Paul: emblems of Catholic identity in Christian literature and art. In Pottery, Pavements and Paradise. Iconographic and Textual Studies on Late Antiquity, ed. A. van den Hoek \& J. J. Jr. Herrmann, 301-326. Leiden: Brill.

Vorster, Ch., 1993. Römische Skulpturen des späten Hellenismus und der Kaiserzeit. Werke nach Vorlagen und Bildformeln des 5. und 4. Jahrhunderts v. Chr. Vatikanische Museen. Museo Gregoriano Profano ex Lateranense, Katalog der Skulpturen, vol. II, 1. Mainz: Zabern.

Weigel, T., 1996. Die Reliefsäulen des Hauptaltarciboriums von San Marco in Venedig. Münster: Rhema. 
Weis, A., 1963. Ein Petruszyklus des 7. Jahrhunderts im Querschiff der Vatikanischen Basilika. RQA 58: 230-270.

Wilpert, J. 2013. Die Malereien der Katakomben Roms. Freiburg: Herder.

Wirbelauer, E. 2016. Primat. RAC 28: 156-183. Stuttgart: Hiersemann.

Wolter, M. 2015. Petrus I (Gestalt). In RAC 27:387-399. Stuttgart: Hiersemann. 